\title{
Penentuan Status Mutu Air dengan Metode Indeks Pencemaran dan Strategi Pengendalian Pencemaran Sungai Ogan Kabupaten Ogan Komering Ulu
}

\author{
Enda Kartika Sari1 ${ }^{1}$ dan Oki Endrata Wijaya²
}

1Dosen Fakultas Teknik Universitas Baturaja, Sumatera Selatan ; e-mail: endah_ubr@ymail.com

2Dosen Fakultas Teknik Universitas Baturaja, Sumatera Selatan

\begin{abstract}
ABSTRAK
Sungai Ogan merupakan sumber air bagi intake PDAM dan pemenuhan kebutuhan sehari-hari masyarakat di Kabupaten Ogan Komering Ulu. Pentingnya peran Sungai Ogan ini maka diperlukannya penentuan kualitas air Sungai Ogan yang bersifat menyeluruh dengan menggunakan paramater kualitas air sungai dan merumuskan strategi pengendalian pencemaan air yang terjadi di Sungai Ogan. Penggunaan indeks kualitas air dapat mempermudah penentuan kualitas air sungai serta mempermudah juga dalam pemberian informasi kepada pihak yang membutuhkan. Tujuan penelitian ini adalah menentukan status mutu air dan strategi pengendalian pencemaran air sungai Ogan Kabupaten Ogan Komering Ulu. Metode yang digunakan dalam penelitian ini adalah metode purposive sampling dengan menggunaan perhitungan indeks pencemaran air di 5 titik lokasi sampling. Penentuan status mutu air menggunakan metode indeks pencemaran menurut Kepmen LH 115/2003. Parameter yang diamati dan diukur ada 10 paramater dengan menggunakan metode Standar Nasional Indonesia (SNI) pengukuran kualitas air dan limbah, Menurut Peraturan Gubernur Sumatera Selatan No 16/2005 meliputi sifat fisika, kimia dan biologi dari badan air sungai yaitu suhu, kekeruhan, TSS, pH, DO, BOD, Nitrat, Phospat, MBAS dan Fecal Coliform. Hasil yang didapatkan Status mutu air dengan menggunakan indeks pencemaran stasiun 1-5. termasuk dalam kategori tercemar ringan dengan kisaran nilai 1,3 - 2,3. Strategi pengendalian pencemaran sungai dapat dilakukan dengan pengurangan beban pencemaran yaitu dengan melibatkan masyarakat dalam pengelolaan lingkungan sungai dan perlu melakukan efektifitas pengelolaan dan manajemen IPAL yang lebih baik yang lebih melibatkan peran serta masyarakat dalam teknis pengelolaannya, serta perlunya pemantauan rutin kualitas air sungai dan memetakan sumber-sumber pencemar potensial pada setiap lokasi sehingga permasalahan akan cepat teratasi.
\end{abstract}

Kata kunci: Kualitas Air, Indeks Pencemaran, Sungai Ogan

\begin{abstract}
The Ogan River is a source of water for the intake of the Ogan Komering Ulu Regency PDAM. This fact is deemed necessary to determine the evaluation of the water quality of the Ogan River which is complex by involving many parameters that affect the water body and needs to formulate a water pollution control strategy that needs to be done. The use of a water quality index can facilitate the determination of the quality of water bodies and also facilitate the provision of information to those in need. The purpose of this study was to determine the status of water quality and the control strategy of Ogan Komering Ulu District water pollution. The method used in this study was purposive sampling method by using the calculation of the water pollution index in 5 sampling locations. Determination of water quality status using the pollution index method according to Kepmen LH 115/2003. The parameters observed and measured were 10 parameters using the Indonesian National Standard (SNI) method of measuring water and waste quality, According to the Governor of South Sumatra Regulation No. 16/2005 covering physical, chemical and biological properties of river water bodies namely temperature, turbidity, TSS, pH, DO, BOD, Nitrate, Phosphate, MBAS and Fecal Coliform. Results obtained status of water quality by using station pollution index 1-5. included in the light polluted category with a range of values $1.3-2.3$. The river pollution control strategy can be carried out by reducing the pollution load by involving the community in managing the river environment and needing to better manage and manage IPALs which involve more community participation in technical management, and the need to routinely monitor river water quality and map resources. potential pollutant sources at each location so that problems will be quickly resolved.
\end{abstract}

Keywords: Water Quality, Pollution Index, Ogan River

Citation: Sari, E.K., dan Wijaya, O.E. (2019). Penentuan Status Mutu Air dengan Metode Indeks Pencemaran dan Strategi Pengendalian Pencemaran Sungai Ogan Kabupaten Ogan Komering Ulu. Jurnal Ilmu Lingkungan, 17(3), 486-491, doi:10.14710/jil.17.3.486-491

\section{Pendahuluan}

Sungai memiliki peran yang sangat penting bagi masyarakat, selain berfungsi untuk pengaliran air kondisi sungai tidak bisa dipisahkan dari aktivitas manusia. Dari total seluruh pasokan air di bumi sebesar 0,036\% dapat diambil dari sungai dan danau 
serta sebesar $76 \%$ air tersebut banyak dimanfaatkan oleh rumah tangga (Kumar Reddy \& Lee, 2012).

Sungai Ogan di Kabupaten Ogan Komering Ulu sebagai sumber utama air baku air minum dan aktivitas sehari-hari masyarakat Ogan Komering Ulu. Sungai ini telah banyak mengalami beban pencemaran di badan sungai akibat perilaku negatif yang dilakukan masyarakat seperti pembuangan limbah domestic dan non domestic (Halder \& Islam, 2015). Penambahan bahan buangan dalam jumlah besar dari hulu ke hilir secara terus menerus akibat aktivitas manusia seperti logam berat, pewarna, obatobatkan, pestisida, fluorida, pestisida dan deterjen memberikan ancaman terbesar sebesar 80 persen terhadap populasi dunia (Kumar Reddy \& Lee, 2012) dan beban polutan tertinggi adalah $\mathrm{Cd}$ dan $\mathrm{Pb}$ yang memberikan ancaman tertinggi terhadap perairan (Islam, Ahmed, Raknuzzaman, Habibullah -AlMamun, \& Islam, 2015). Kenyataan-kenyataan tersebut mengakibatkan menurunnya kualitas air sungai dan berpengaruh terhadap kondisi fisik, kimia dan biologinya.

Evaluasi terhadap kualitas air sungai sangatlah penting dilakukan untuk mengetahui status mutu air dari sungai tersebut. Melalui Water Framework Directive (WFD), negara di eropa mulai melakukan pengelolaan Daerah Aliran Sungai (DAS) Terpadu untuk mencari status mutu baik dari badan air sungai (Tsakiris \& Alexakis, 2012). Penentuan status mutu air dapat menggunakan metode indeks kualitas air (WQI) dan bakat kualitas air (WQA) (Fulazzaky,
2010). Nilai kualitas air sungai Ogan berdasarkan NSF-WQI adalah klasifikasi sedang dengan nilai 55-56 (Yulistia, Fauziyah, \& Hermansyah, 2018) namun penggunaan indeks kualitas air dengan WQI tidaklah efektif karena banyak parameter penting tidak ada dalam formula seperti nutrisi, logam berat dan coliform (Naubi, Zardari, Shirazi, Ibrahim, \& Baloo, 2016). Parameter yang digunakan untuk menentukan status mutu air adalah parameter berdasarkan baku mutu kualitas air sungai menurut PP Nomor 82 Tahun 2001 dengan nilai indeks pencemaran kualitas air baik bernilai 0,728-0,892 (Effendi, 2016). Paramater ini paling relevan untuk menentukan kualitas air sungai seperti zat karbon terlarut, oksidasi amonium, desentrifikasi, keseimbangan oksigen dan proses degradasi (Mannina \& Viviani, 2010). Dalam melakukan pengukuran terhadap parameter kualitas air perlu dilakukan secara terpadu agar perumusan strategi pengendalian pencemaran dapat dilakukan dengan baik. Penelitian ini bertujuan menganalisis status kualitas air di Sungai Ogan berdasarkan indeks kualitas air dengan metode indeks pencemaran serta merumuskan prioritas strategi pengendalian pencemaran air sungai.

\section{Metode}

Penelitian dilaksanakan di wilayah perairan Sungai Ogan di Kota Baturaja Kabupaten Ogan Komering Ulu, Provinsi Sumatera Selatan, titik koordinat lokasi sampling akan disajikan pada Tabel 1.

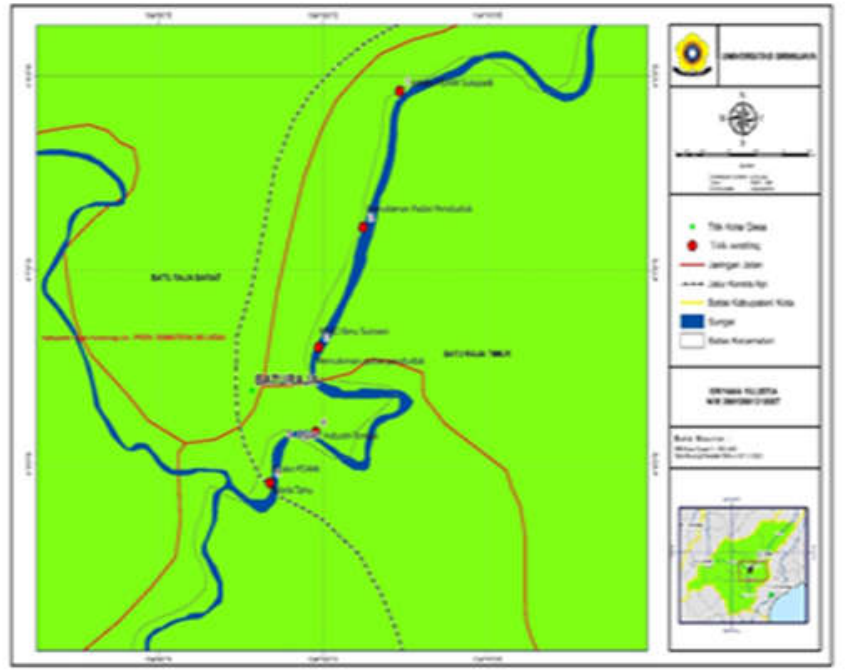

Gambar 1 Peta lokasi penelitian

Tabel 1. Lokasi Titik Sampling

\begin{tabular}{|c|c|c|c|c|}
\hline \multicolumn{2}{|c|}{ Titik Sampling } & Keterangan & Lintang & Bujur \\
\hline Stasiun & 1 & Hulu sungai Desa Tanjung Agung terdapat Intake pipa PDAM & $04^{\circ} 07^{\prime} 974^{\prime \prime}$ & $104^{\circ} 09^{\prime} 102^{\prime \prime}$ \\
\hline Stasiun & 2 & Desa Kebun Jeruk terdapat industri rumah tangga tempe dan tahu & $04^{\circ} 08^{\prime} 115^{\prime \prime}$ & $104^{\circ} 09^{\prime} 550^{\prime \prime}$ \\
\hline Stasiun & 3 & Kelurahan Kemalaraja, pemukiman padat penduduk & $04^{\circ} 07^{\prime} 618^{\prime \prime}$ & $104^{\circ} 10^{\prime} 161^{\prime \prime}$ \\
\hline Stasiun & 4 & Kelurahan Air gading, pemukiman padat penduduk & $04^{\circ} 06^{\prime} 759^{\prime \prime}$ & $104^{\circ} 10^{\prime} 248^{\prime \prime}$ \\
\hline Stasiun & 5 & Hilir sungai Desa Sukajadi terdapat Intake pipa PDAM & $04^{\circ} 06^{\prime} 934^{\prime \prime}$ & $104^{\circ} 10^{\prime} 251^{\prime \prime}$ \\
\hline
\end{tabular}


Parameter yang diamati dan diukur ada 10 paramater dengan menggunakan metode Standar Nasional Indonesia (SNI) pengukuran kualitas air dan limbah, Menurut Peraturan Gubernur Sumatera Selatan no 16/2005 masing-masing metode yaitu Kekeruhan (SNI 6989.25-2005), Suhu air (SNI 06.6989.23-2005), pH (SNI 06.6989.11-2004), DO (manual alat), BOD ( SNI 6989.72-2009), TSS (SNI 066989.3-2004), Pospat (15.26/IK/LL/2017), Nitrat (SNI 06-2480-1991). MBAS ( SNI 06.6989.51-2005) dan Fecal Coliform (23-1991-09). Pengambilan sampel parameter tersebut dilakukan pada pagi dan sore hari dengan 3 kali ulangan.

Analisis kualitas air dengan menggunakan metode indeks pencemaran menurut Keputusan Menteri Lingkungan Hidup No 115/2003 Lampiran II tentang penentuan status mutu air, untuk mengetahui tingkat pencemaran sungai dengan menggunakan Rumus sebagai berikut:

$$
I P j=\sqrt{\frac{\left(\frac{C i}{L i j}\right)^{2} M+\left(\frac{C i}{L i j}\right)^{2} R}{2}}
$$

Dimana :

$\mathrm{IPj} \quad=$ indeks pencemaran bagi peruntukan $\mathrm{j}$

$\mathrm{Ci}=$ konsentrasi paramater kualitas air $\mathrm{i}$

Lij = konsentrasi parameter kualitas air i yang tercantum dalam baku peruntukkan air $\mathrm{j}$

$\mathrm{M} \quad=$ Maksimum

$\mathrm{R}=$ Rerata

Nilai kualitas air IP ditentukan dari result nilai maksimum dan nilai rerata rasio konsentrasi per parameter terhadap nilai baku mutunya. Kelas indeks IP ada 4 yaitu:

$\begin{array}{ll}\text { Skor } 0 \leq \mathrm{Pij} \leq 1,0 & \text { Baik (good) } \\ \text { Skor } 1,0<\mathrm{Pij} \leq 5,0 & \begin{array}{l}\text { Tercemar ringan } \\ \text { (slightly polluted) } \\ \text { Tercemar sedang } \\ \text { (fairly polluted) } \\ \text { Tercemar berat }\end{array} \text {, } 0<\mathrm{Pij} \leq 10 \\ \text { Skor Pij }>10 & \text { (heavily olluted) }\end{array}$

\section{Hasil dan Pembahasan}

Hasil pemantauan yang dilakukan di Sungai Ogan dengan menggunakan parameter pencemar kualitas air yang ditinjau dalam penelitian ini yaitu Temperatur, TSS, Kekeruhan, pH, DO, BOD, Nitrat, Phospat, MBAS dan Fecal Coliform. Parameter tersebut kemudian dibandingkan dengan Peraturan Pemerintah Nomor 82 Tahun 2001 tentang Pengelolaan Kualitas Air dan Pengendalian Pencemaran Air untuk selanjutnya dapat mengetahui mutu air sungai berdasarkan metode Indeks Pencemaran. Kegiatan pengambilan sampel air dilakukan pada bulan Maret tahun 2019. Hasil penilaian dari masing-masing parameter dapat dilihat pada Gambar 2 - Gambar 10.

\subsection{Total PadatanTersuspensi (TSS)}

Total Padatan Tersuspensi TSS di Sungai Ogan berkisar antara 12,4-268 mg / L. Nilai Total Padatan Tersuspensi (TSS) di 5 stasiun pemantauan yang tertinggi ada di stasiun 3 yaitu Kelurahan Kemalaraja yang padat penduduknya dengan nilai TSS tertinggi sebesar $268 \mathrm{mg} / \mathrm{L}$ di pagi hari. Kondisi pagi hari semua aktifitas rumah tangga seperti mandi dan mencuci yang banyak menggunakan air sungai sehingga mengakibatkan TSS air sungai menjadi tinggi. Selain itu debit sungai di pagi hari seringkali meningkat dimana airnya berasal dari hulu sungai sehingga mengakibatkan konsentrasi sedimentasi tersuspensi juga meningkat. Menurut Satriadi dan Sugeng (2004) air pasang dari hulu sungai akan membawa total padatan tersuspensi sehingga konsentrasi padatan tersuspensi menjadi tinggi Menurut Peraturan Gubernur Sumatera Selatan No 16/2005 nilai baku mutu parameter TSS adalah 50 $\mathrm{mg} / \mathrm{L}$, hal ini menunjukkan bahwa parameter TSS Sungai Ogan sudah melebih baku mutu kualitas air. Hasil pengujian Total Padatan Tersuspensi air Sungai Ogan dapat diihat pada Gambar 2.

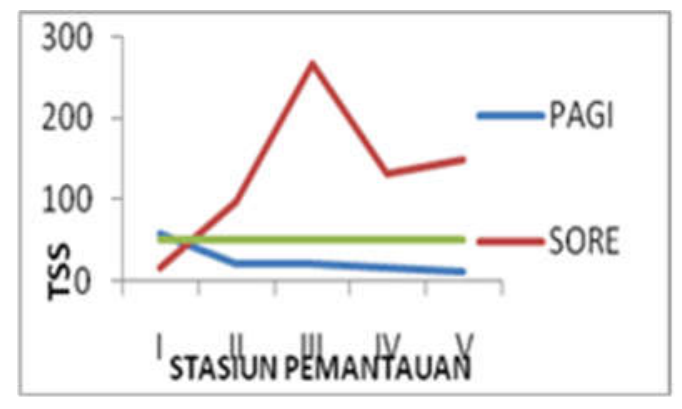

Gambar 2 Total Padatan Tersuspensi di Stasiun Pemantauan

\subsection{Kekeruhan}

Nilai kekeruhan air di Sungai Ogan berkisar antara 13,8- 326 NTU. Tingkat kekeruhan yang tertinggi juga terdapat di stasiun 3 yaitu Kelurahan Kemalaraja yang padat penduduknya. Hal ini berbanding lurus dengan nilai Total Padatan Tersuspensi (TSS) dilokasi tersebut yang juga bernilai tinggi. Nilai tertinggi kekeruhan sebesar 326 NTU dipagi hari. Sumber kekeruhan air sungai di pagi hari berasal dari aktifitas masyarakat yang banyak menggunakan air sungai di pagi hari untuk kebutuhan mencuci, mandi dan lain-lain. Selain itu air bawaan dari hulu sungai yang memiliki kekeruhan tinggi di bandingkan hilir sungai terutama saat kondisi air pasang. Menurut (Yulistia, Fauziyah, \& Hermansyah, 2018), Kekeruhan di hulu Sungai Ogan lebih tinggi dari kekeruhan di hilir. Hal ini dipengaruhi oleh kegiatan budidaya tanaman yang berkontribusi terhadap limpasan kehilangan tanah. Nilai kekeruhan air sungai Ogan di lokasi penelitian dapat dilihat pada Gambar 3. 


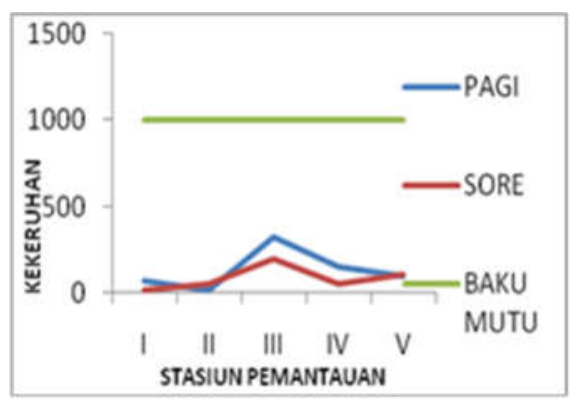

Gambar 3 Kekeruhan di Stasiun Pemantauan

\subsection{Suhu}

Temperatur atau suhu di Sungai Ogan berkisar antara 26 0C hingga 27 0C. Menurut Peraturan Gubernur Sumatera Selatan No 16/2005, mendefinisikan penyimpangan suhu adalah 3 Jadi, suhu air Sungai Ogan di 5 stasiun masih memenuhi standar kualitas air. Suhu memiliki pengaruh signifikan terhadap ekosistem perairan. Menurut Habib dan Khatami (2015) pola suhu dalam ekosistem perairan diubah oleh banyak faktor diantaranya adalah kelembaban dan sinar matahari Paparan sinar matahari merupakan faktor utama yang memegang efek besar yang mempengaruhi suhu air. Nilai suhu dilokasi penelitian dapat dilihat pada Gambar 4.

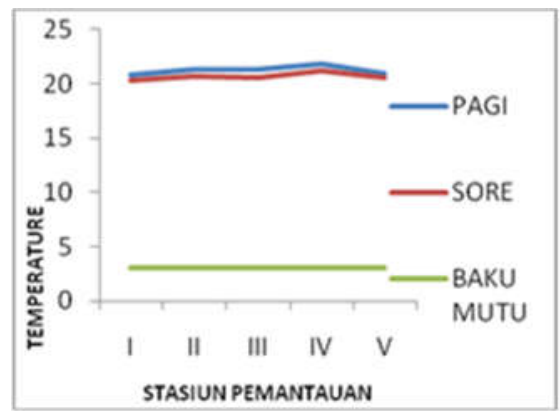

\section{4. $\mathrm{pH}$}

Gambar 4 Temperatur di Stasiun Pemantauan

Konsentrasi pH air di Sungai Ogan berkisar 7,0 7,7. $\mathrm{pH}$ adalah salah satu faktor terpenting yang melayani indeks untuk polusi. pH memiliki efek langsung pada kehidupan di ekosistem. Menurut Peraturan Gubernur Sumatera Selatan no 16/2005 nilai baku mutu untuk pH adalah 6-9 (Kelas I), itu berarti pH dalam air Sungai Ogan masih memenuhi standar baku mutu kualitas air.

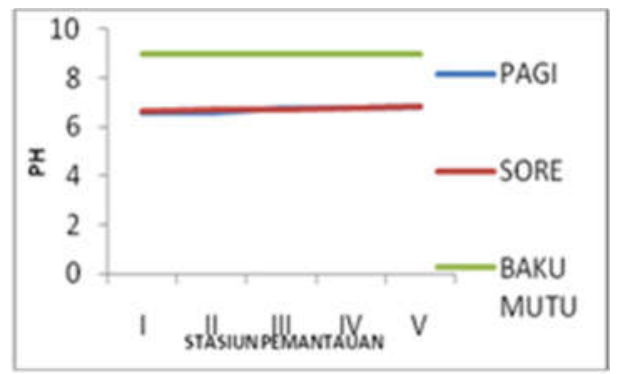

Gambar $\mathbf{5}$ pH di Stasiun Pemantauan

\subsection{DO}

Dari Gambar 5 terlihat bahwa nilai Do tertinggi terdapat pada stasiun 5 baik di pagi hari maupun di sore hari dengan nilai DO 9,6 mg/L. DO adalah jumlah oksigen terlarut dalam air yang berasal dari fotosintesa dan absorbsi atmosfer/udara. Semakin banyak jumlah DO maka kualitas air semakin baik. Level DO sungai yang tidak tercemar berkisar antara 80\% -100\% (Effendi, Kristianiarso, Adiwilaga, 2013) Konsentrasi DO di bawah $5 \mathrm{mg} / \mathrm{L}$ terdapat pada stasiun 2 dengan nilai DO 4,91 mg/L. Nilai DO yang rendah dikarenakan proses fotosintesis oleh fitoplankton didasar sungai sangat rendah sehingga kadar oksigen terlarut dalam air menjadi rendah. Hal ini dapat mempengaruhi kinerja dan kelangsungan hidup komunitas biologis, dan di bawah $2 \mathrm{mg}$ / L dapat menyebabkan kematian ikan (Yulistia, Fauziyah, \& Hermansyah, 2018), Menurut Peraturan Gubernur Sumatera Selatan no $16 / 2005$, nilai baku mutu untuk DO adalah $6 \mathrm{mg}$ / L. Stasiun 2 tidak mencapai standar baku mutu kualitas air. Nilai DO air Sungai Ogan di lokasi penelitian dapat dilihat pada Gambar 6.

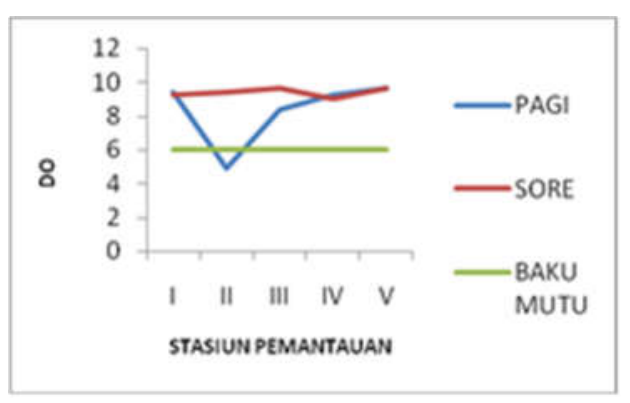

Gambar 6 DO di 5 Stasiun Pemantauan

\subsection{BOD}

Nilai BOD di Sungai Ogan berkisar antara 1,21$4,57 \mathrm{mg} / \mathrm{L}$. BOD tertinggi di Sungai Ogan mencapai $4,57 \mathrm{mg} / \mathrm{L}$ distasiun 2 di pagi hari. Di lokasi ini terdapat industri rumah tangga tempe dan tahu. Pembuangan limbah cair dari industri tahu yang banyak mengandung bahan organik mengakibatkan konsentrasi BOD air sungai menjadi tinggi. Makin besar konsentrasi BOD suatu perairan, menunjukan konsentrasi bahan organik di dalam air juga tinggi (Yudo, 2010 dalam Ali dkk., 2013) Menurut Peraturan Gubernur Sumatera Selatan no 16/2005, Nilai baku mutu untuk BOD adalah $2 \mathrm{mg} / \mathrm{L}$. Di stasiun 2 pada pagi hari nilai BOD telah melebihi nilai standar baku mutu kualitas air. Nilai BOD air Sungai Ogan di lokasi penelitian dapat dilihat pada Gambar 7.

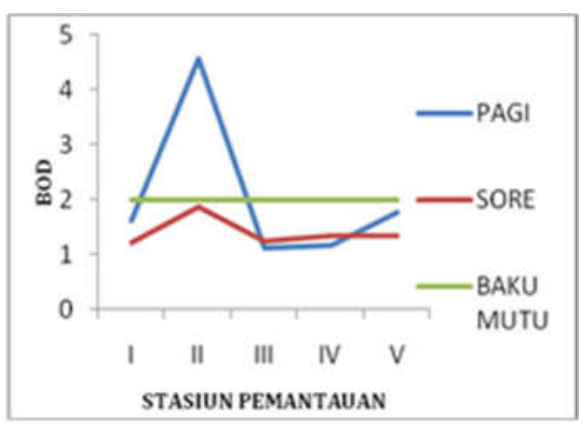

Gambar 7 BOD di 5 Stasiun Pemantauan

\subsection{Nitrat}

Konsentrasi nitrat di Sungai Ogan berkisar 0,05$0,3 \mathrm{mg} / \mathrm{L}$. Konsentrasi nitrat tertinggi ditemukan di stasiun 3 di sore hari. Lokasi ini adalah Kelurahan Kemalaraja yang padat penduduknya. Kondisi 
masyarakat yang banyak memanfaatkan Sungai Ogan untuk kebutuhan dan aktifitas rumah tangga yang banyak menghasilkan limbah domestik rumah tangga sehingga menimbulkan polusi difus yang dapat mengakibatkan peningkatan nitrat dan bahan organik dalam air. Menurut Peraturan Gubernur Sumatera Selatan no 16/2005, nilai baku mutu nitrat adalah 10 mg / L, untuk itu konsentrasi nitrat air Sungai Ogan tetap memenuhi kriteria yang disyaratkan. Konsentrasi Nitrat di Sungai Ogan di lokasi penelitiandapat dilihat pada Gambar 8.

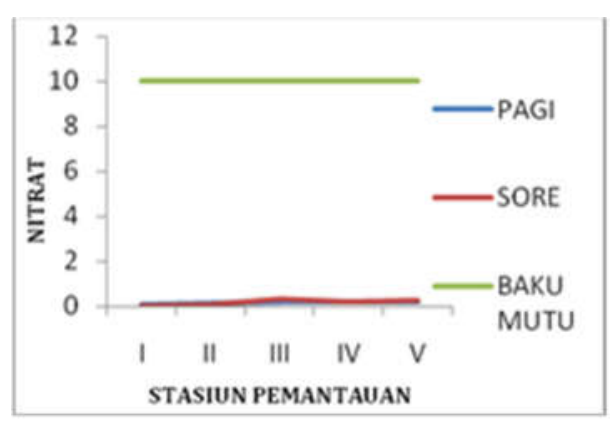

\subsection{Posphat}

Gambar 8 Nitrat di Stasiun Pemantauan

Konsentrasi fosfat di Sungai Ogan berkisar antara 0,01-0,64 mg / L. Konsentrasi tertinggi ditemukan di stasiun 3 di pagi hari dengan nilai 0,63 $\mathrm{mg} / \mathrm{L}$ dan disore hari dengan nilai $0,64 \mathrm{mg} / \mathrm{L}$. Fosfor adalah komponen limbah, karena unsur ini sangat penting dalam metabolisme, dan selalu ada dalam limbah metabolisme hewan. Fosfor terjadi dalam keadaan teroksidasi penuh (fosfat) dalam air (Menurut Bhadra, et.al 2014 dalam Yulistia, Fauziyah, \& Hermansyah, 2018) Ketentuan Gubernur Sumatera Selatan No 16/2005, standar kualitas untuk fosfat adalah 0,2 mg/ L. Jadi, konsentrasi fosfat Sungai Ogan telah melebihi kriteria yang disyaratkan. Nilai phospat air Sungai Ogan di lokasi penelitian dapat dilihat pada Gambar 9.

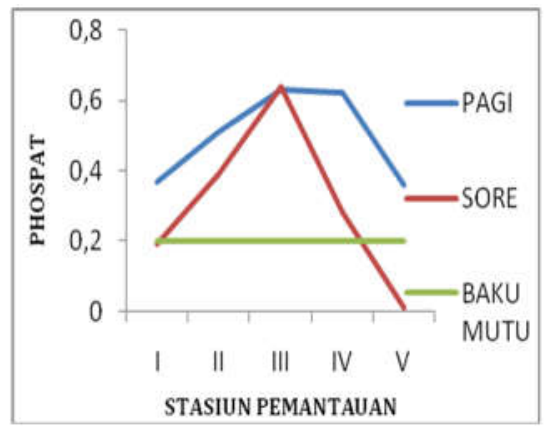

Gambar 9 Posphat di Stasiun Pemantauan

\subsection{MBAS}

Dari Gambar 10 terlihat bahwa konsentrasi MBAS Sungai Ogan berkisar antara 0,005-1,88 ml. Konsentrasi MBAS tertinggi ditemukan di stasiun 5 di pagi hari dengan nilai $1,88 \mathrm{mg} / \mathrm{L}$. MBAS adalah Methylen Blue Active Surfactant yakni menambahkan zat metilen biru yang akan berikatan dengan surfaktan dan dianalisis dengan spektrofotometer UVVis. MBAS digunakan untuk menganalisis kadar surfaktan anion atau deterjen pada sampel beberapa limbah. Menurut Peraturan Gubernur Sumatera Selatan no 16/2005, nilai baku mutu MBAS adalah 0,2 mg / L. Semua titik pantau telah memenuhi kualitas baku mutu kecuali untuk stasiun 5 di pagi hari yang melebihi kriteria yang disyaratkan.

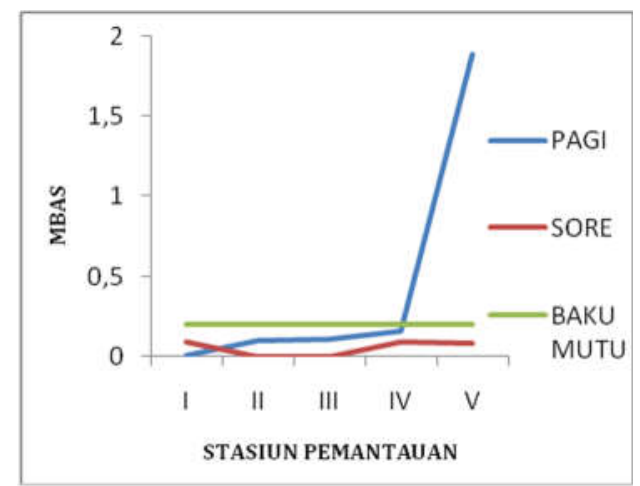

Gambar 10 MBAS di 5 Stasiun Pemantauan

\subsection{Fecal Coliform}

Bakteri coliform adalah organisme indikator untuk keberadaan patogen dalam sampel air. Berdasarkan Ketentuan Gubernur Sumatera Selatan No. 16/2005 standar kualitas bakteri coliform adalah $100 / \mathrm{ml}$. Hasil dari laboratorium menunjukkan bahwa bakteri fecal coliform bernilai negatif di 5 stasiun pemantauan artinya air sungai ogan memnuhi kriteria yang disyaratkan.

\subsection{Penentuan Status Mutu Air dengan Metode Indeks Pencemaran}

Indeks pencemaran merupakan salah satu metoda yang digunakan untuk menentukan status mutu air. Status mutu air menunjukkan tingkat kondisi mutu air sumber dengan membandingkan baku mutu yang telah ditetapkan. Nilai indeks pencemaran dapat dilihat pada Tabel 2 .

Tabel 2. Nilai Indeks Pencemaran di Sungai Ogan

\begin{tabular}{cccc}
\hline No & Stasiun & Indeks Pencemaran & Status Mutu \\
\hline 1 & I & 1,4 & Tercemar ringan \\
2 & II & 1,9 & Tercemar ringan \\
3 & III & 2,3 & Tercemar ringan \\
4 & IV & 2,3 & Tercemar ringan \\
5 & V & 1,3 & Tercemar ringan \\
\hline
\end{tabular}


Dari Tabel 2 berdasarkan KepMenLH No 115 Tahun 2003 tentang pedoman Penentuan Status Mutu Air berdasarkan indeks pencemaran terlihat bahwa pada stasiun 1 - 5 mempunyai status mutu air tercemar ringan, dengan nilai ndeks pencemaran tertinggi terdapat pada stasiun 3 dan 4 yaitu 2,3. Lokasi stasiun 3 dan 4 adalah lokasi pemukiman yang padat penduduknya yang mempunyai kemungkinan air sungai mengalami pencemaran ringan.

\subsection{Strategi Pengendalian Pencemaran Sungai}

Dari hasil penelitian didapatkan bahwa status mutu air Sungai Ogan pada Stasiun 1 - 5 status mutu air tercemar ringan. Oleh karena itu diperlukan upaya dan strategi pengendalian untuk mengurangi pencemaran di Sungai Ogan.

Lokasi Stasiun 3 dan 4 memiliki nilai indeks pencemaran yang tinggi dibandingkan stasiun lainnya. Lokasinya adalah Kelurahan Kemalaraja, Airgading yang sangat padat penduduknya. Upaya pengendalian yang dapat dilakukan di lokasi ini adalah: 1) Perlu dilakukannya pengurangan beban pencemaran yaitu dengan melibatkan masyarakat dalam pengelolaan lingkungan sungai dan perlu melakukan efektifitas pengelolaan dan manajemen IPAL yang lebih baik yang lebih melibatkan peran serta masyarakat dalam teknis pengelolaannya, 2) Untuk pemukiman penduduk yang padat perlu kesadaran masyarakat dalam pengelolaan sampah rumah tangga serta tidak membuang sampah di badan Sungai Ogan, 3) Perlu adanya peningkatan penegakan hukum kepada industri tempe atau pelaku lain yang mencemari sungai dan bekerjasama dengan masyarakat untuk melakukan pengawasan terhadap industri tempe agar tidak membuang limbah industri langsung ke sungai, dan bila industri tersebut melakukan pelanggaran hendaknya diberikan sangsi hukum yang tegas kepada pihak industri tersebut, 4) Perlunya pemantauan rutin kualitas air sungai dan memetakan sumber-sumber pencemar potensial pada lokasi ini sehingga permasalahan akan cepat teratasi. Dan 5) Perlunya efektifitas pengelolaan IPAL komunal bagi masyarakat sehingga limbah yang dihasilkan oleh industri dan masyarakat umum tidak membahayakan bagi Sungai Ogan khususnya dan lingkungan umumnya.

\section{Kesimpulan}

a. Status mutu air dengan menggunakan indeks pencemaran stasiun 1-5 termasuk dalam kategori tercemar ringan dengan kisaran nilai $1,3-2,3$.

b. Strategi pengendalian pencemaran sungai dapat dilakukan dengan pengurangan beban pencemaran yaitu dengan melibatkan masyarakat dalam pengelolaan lingkungan sungai dan perlu melakukan efektifitas pengelolaan dan manajemen IPAL yang lebih baik yang lebih melibatkan peran serta masyarakat dalam teknis pengelolaannya, serta perlunya pemantauan rutin kualitas air sungai dan memetakan sumber-sumber pencemar potensial pada setiap lokasi sehingga permasalahan akan cepat teratasi

\section{DAFTAR PUSTAKA}

Ali, A., Soemarno Mangku P. 2013. Kajian Kualitas Air dan Status Mutu Air Sungai Metro di Kecamatan Sikam Kota Malang. Jurnal Bumi Lestari, 13(2), 265-274.

A.G. Habibb, SH Khatami, "Survey of the water quality of Bahar Country Stream (Iran) by NSFWQI", Environ Conserv, J. 16(1):395-403, No 2, pp 81-92, 2013.

Effendi, H. (2016). River Water Quality Preliminary Rapid Assessment Using Pollution Index. Procedia Environmental Sciences. https://doi.org/10.1016/j.proenv.2016.03.108

Fulazzaky, M. A. (2010). Water quality evaluation system to assess the status and the suitability of the Citarum river water to different uses. Environmental Monitoring and Assessment. https://doi.org/10.1007/s10661-009-1142-z

Halder, J., \& Islam, N. (2015). Water Pollution and its Impact on the Human Health. Journal of Environment and Human. https://doi.org/10.15764/eh.2015.01005

H. Effendi, A.A., Kristianiarso, E.M. Adiwilaga, "Karateristik Kualitas Air Sungai Cihideung, Kabupaten Bogor, Jawa Barat", Ecolab Jurnal. Vol 7, No 2, pp 81-92, 2013.

Islam, M. S., Ahmed, M. K., Raknuzzaman, M., Habibullah -AlMamun, M., \& Islam, M. K. (2015). Heavy metal pollution in surface water and sediment: A preliminary assessment of an urban river in a developing country. Ecological Indicators. https://doi.org/10.1016/j.ecolind.2014.08.016

Keputusan Menteri Lingkungan Hidup No 115/2003 Lampiran II tentang penentuan status mutu air.

Kumar Reddy, D. H., \& Lee, S. M. (2012). Water Pollution and Treatment Technologies. Journal of Environmental \& Analytical Toxicology. https://doi.org/10.4172/2161-0525.1000e103

Mannina, G., \& Viviani, G. (2010). Water quality modelling for ephemeral rivers: Model development and parameter assessment. Journal of Hydrology. https://doi.org/10.1016/j.jhydrol.2010.08.015

Mutu Air. Kepmen LH No. 115 Tahun 2003.

Naubi, I., Zardari, N. H., Shirazi, S. M., Ibrahim, N. F. B., \& Baloo, L. (2016). Effectiveness of water quality index for monitoring Malaysian river water quality. Polish Journal of Environmental Studies. https://doi.org/10.15244/pjoes/60109

Peraturan Pemerintah Republik Indonesia No.82 Tahun 2001 tentang Pengelolaan Kualitas Air dan Pengendalian Pencemaran Air

Satriadi, A dan W. Sugeng (2004). Distribusi Muatan Padatan Tersuspensi di Muara Sungai Bodri Kabupaten Kendal. J. Ilmu Kelautan, 9(2), 101-107.

Tsakiris, G., \& Alexakis, D. (2012). Water quality models : An overview. European Water.

Yulistia, E., Fauziyah, S., \& Hermansyah, H. (2018). Assessment of Ogan River Water Quality Kabupaten OKU SUMSEL by NSFWQI Method. Indonesian Journal of Fundamental and Applied Chemistry. https://doi.org/10.24845/ijfac.v3.i2.54 